CREDIT Research Paper

No. 00/4

\title{
Multilateral Market Access Negotiations in Goods and Services
}

by

Sam Laird

Centre for Research in Economic Development and International Trade, University of Nottingham 
The Centre for Research in Economic Development and International Trade is based in the School of Economics at the University of Nottingham. It aims to promote research in all aspects of economic development and international trade on both a long term and a short term basis. To this end, CREDIT organises seminar series on Development Economics, acts as a point for collaborative research with other UK and overseas institutions and publishes research papers on topics central to its interests. A list of CREDIT Research Papers is given on the final page of this publication.

Authors who wish to submit a paper for publication should send their manuscript to the Editor of the CREDIT Research Papers, Professor M F Bleaney, at:

Centre for Research in Economic Development and International Trade,

School of Economics,

University of Nottingham,

University Park,

Nottingham, NG7 2RD,

UNITED KINGDOM

Telephone (0115) 9515620

Fax: (0115) 9514159

CREDIT Research Papers are distributed free of charge to members of the Centre. Enquiries concerning copies of individual Research Papers or CREDIT membership should be addressed to the CREDIT Secretary at the above address. 
CREDIT Research Paper

CREDIT

No.

$00 / 4$

\section{Multilateral Market Access Negotiations in Goods and Services}

by

Sam Laird

Centre for Research in Economic Development and International Trade, University of Nottingham 


\section{The Author}

Sam Laird is Counsellor, Development Division, WTO, and Special Professor of International Economics, University of Nottingham.

\section{Acknowledgements}

The views expressed in this paper are those of the author and do not necessarily represent the views of the World Trade Organization or its Member States. Helpful comments on an earlier draft were received from Rolf Adlung and Costas Michalopoulos.

May 2000 


\title{
Multilateral Market Access Negotiations in Goods and Services
}

by

Sam Laird

\begin{abstract}
Overall, protection in goods and services now appears modest in developed and developing countries, but there are a number of products where protection remains high and liberalization could bring important benefits to developing countries. In absolute terms the greatest gains for developing countries as a group are likely to come from negotiations to address tariff peaks and escalation in manufactures, but, as a result of the failure of the WTO Ministerial Session in Seattle, these are not part of the current WTO agenda. However, in proportion to their production, agriculture is even more important for a number of developing countries, and agreed negotiations will address tariffs, domestic supports and export subsidies. Other non-tariff barriers affecting trade in goods will be mainly covered in any revision of WTO rules. In services, the mandated market access negotiations will attempt to extend sectoral specific commitments and reduce the scope of MFN exemptions, but negotiations on certain rules and disciplines, including safeguards, subsidies, government procurement of services will also be important. Strategically, it would be preferable to reduce intervention of all forms and across all sectors starting where such intervention is more important, although this requires further work on estimating the effects of non-tariff interventions in goods and services.
\end{abstract}

\section{Outline}

1. Introduction

2. Levels and Patterns of Protection

3. Liberalization Strategies 



\section{INTRODUCTION}

Protection in goods and services has changed markedly in recent years, but despite the free-trade hype by some opponents of globalization, there is still substantial protection in developed and developing countries and this is loaded against developing countries (Section II). Under the WTO Agreements, many non-tariff measures in agriculture were converted to tariffs ("tariffied") and quantitative restrictions on trade in textiles and clothing are being eliminated, making tariffs the binding constraint in key goods sectors, tariff peaks and escalation will need to be addressed in conventional market access negotiations. Market access negotiations will also be the principal means for addressing other barriers in the agricultural sector as well as in services. Much intervention on trade or production in goods and services is regulated by WTO rules, and any further negotiated reductions in the incidence of such measures would come under negotiations on such rules. While it is difficult to quantify the effects of existing protection and other forms of sectoral intervention, particularly in the services sector, it is possible to draw some conclusions about a welfare-enhancing liberalization strategy for the new negotiations (Section III).

\section{LEVELS AND PATTERNS OF PROTECTION}

\section{A. TARIFFS}

Overall, most favoured nation (MFN) bound tariffs at the end of the implementation of the Uruguay Round results will be some 6.5 per cent across all countries and products (Table 1), while applied rates will be some 4.3 per cent. In general, developing countries' bound rates are higher than those of the developed countries and, for some regions, there is a large gap between their applied and bound rates. The binding coverage, which increased substantially for all regions in the Uruguay Round, is also lower for developing regions outside Latin America. To a large degree, the higher rates and the lower binding coverage for developing countries are a remnant of earlier import substitution industrialization (ISI) strategies, and the application of special and differential treatment meant that no serious demands had been made on them to lower tariff rates. The reduction of their applied rates, especially in the last decade, and the increase in binding coverage reflect a shift towards more open economies and a belief that it was necessary 
to participate more fully in negotiations in order to obtain improved access for their exports.

Nevertheless, protection is still quite high in sensitive product areas such as textiles and clothing and transport equipment (Table 2), where trade is large and imports are relatively responsive to price changes. In addition, most developed and developing countries show substantial tariff escalation: uniform tariffs are rare exceptions, applied, with minor exceptions in Chile; Peru; Hong Kong, China; and Singapore (in the latter two cases at zero). An analysis of tariff escalation by industrial countries in the post-Uruguay Round era shows a substantial loading against imports from developing countries, making it more difficult for them to develop downstream processing (Table 3). Michalpoulos (1999), based on WTO Trade Policy Reviews of some 42 developing countries, shows that marked escalation is also a feature of most of their tariff structures. Thus, how to eliminate or reduce tariff peaks and escalation is one of the key questions to be addressed in future negotations.

To some degree, the problem of high trade barriers may be overstated because of the growing importance of regional trade agreements (RTAs) and preferences, including between developing countries as well as between developed countries and countries at different stages of development. Examples are AFTA, APEC, CACM, the Canada-Chile FTA, CARICOM, COMESA, the Europe Agreements, MERCOSUR, NAFTA, SADC, etc. These agreements seem to have been given a stimulus to intra-regional trade, raising fears of trade diversion. However, in some of the smaller faster growing RTAs, trade with third countries is growing faster than world trade in general and the EU's trade with members and non-members is growing at an equivalent rate (Crawford and Laird, 2000). Nevertheless, there must be some concern about the widely varying preferential rules of origin which are not subject to WTO disciplines. Even the Pan-European System of Cumulation of Origin, now being applied in the Europe Agreements of the EU and EFTA with the other European countries, has over 100 pages of detailed rules. The overlapping of RTAs, with different product coverage and implementation periods adds to the complexity of trade regimes. 
Previous multilateral rounds have reduced the importance of GSP, and other unilateral preference schemes such as the Lomé Convention and the Caribbean Basin Initiative now offer better treatment than GSP. While these schemes have facilitated market access for developing countries to developed country markets, the benefits have been captured by relatively few exporters and there have also been important exclusions. To some extent they diverted attention from the need to undertake policy reforms in the developing countries, that has only been addressed in the last decade. Consideration is currently being given to replacing ACP preferences with a series of reciprocal regional trade agreements centred on the EU; while this will imply some liberalization by developing country partners, the hub and spoke nature of such arrangements will reduce the potential benefits from a wider liberalization, and these countries should also be looking at multilateral negotiations to gain wider benefits than are possible from regional schemes alone.

There are several additional features of tariff protection that might usefully be addressed in the market access negotiations. For example, as a result of tariffication in agriculture, there has now been a major expansion in the use of specific, mixed and compound tariff rates for which it is often difficult to estimate the ad valorem equivalence. Again, many countries use schemes for concessional entry of certain types of goods, e.g., related to investment, industrial promotion or regional development schemes, and these can be used to favour imports from certain trading partners, but there are no disciplines on the use of such schemes other than those under the Agreement on Trade-Related Investment Measures (TRIMs). There are also no disciplines on the use of the FOB or CIF value for duty purposes, and in at least one case there is differential treatment of an RTA partner in the implementation period. Finally, in the Uruguay Round, other charges on imports were to be listed in schedule and included within a global binding commitment. However, the practical application of this provision lacks clarity, mainly because some additional charges are for services, e.g. port fees,. inspection fees, statistical taxes, etc., yet in some instances these are levied on an ad valorem basis unrelated to the value of the service. 


\section{B. NON-TARIFF MEASURES}

\section{Goods}

The Uruguay Round had a major impact on the incidence NTMs, reducing their use and further reductions are expected as commitments continue to be implemented over agreed phase-in periods. Under the Single Undertaking of the Uruguay Round, commitments in respect of NTMs affect both developed and developing countries, with the latter often having extended implementation periods, whereas previously developing countries, invoking GATT provisions on special and differential treatment were able to avoid many of the commitments of the developed countries.

For the developed countries, a representative picture of the pre- and post-Uruguay Round NTMs by broad type and sectoral coverage in OECD countries is given in Tables 5 and 6 . The two outstanding features of these tables are the reduction in the use of NTMs in agriculture, principally through tariffication or elimination of prohibited measures, and the reduced application of export restraints in the area of textiles and clothing.

The major reduction in the use export restraints is related to the prohibition in the use of voluntary export restraints under Article 11 of the WTO Agreement on Safeguards. Remaining VERs, including the EU-Japan consensus on automobiles, are to be eliminated by the end of 1999; other significant export restraints are those under the WTO Agreement on Textiles and Clothing, which replaced the Multi-fibre Agreement (MFA). There are two effects of this prohibition on VERs: first, in a number of cases, mainly in the iron and steel industry, the VERs were replaced by anti-dumping measures; and, second, some flexibility was introduced into the application of safeguards, allowing discrimination among suppliers in exceptional circumstances (although their use continues to be rare). In anti-dumping cases, a common outcome is now negotiated price undertakings by suppliers, voluntary export price restraints (VEPRs), which are similar in effect to VERs.

The phase-out of the MFA and the gradual integration of the textiles and clothing sector within the normal WTO rules is being effected over a 10 year period under the 
supervision of a Textiles Monitoring Body (TMB). Under the Agreement on Textiles and Clothing, which is intended to include products from four different groups (tops and yarn, fabrics, made-up textiles, and clothing), a minimum of 16 per cent of total 1990 volume of imports covered by the MFA was integrated into the WTO in 1995. At least another 17 per cent of the value of 1990 imports was due to be integrated following the third year of the phase-out period. An additional minimum of 18 per cent is to be integrated after the seventh year, while the remaining 41 per cent will be brought under WTO rules at the very end of the phase-out period. Quota restrictions are being expanded by the amount of the prevailing quota growth rates plus 16 per cent annually for the first three years. A further expansion of 25 per cent will take place in the subsequent four years, and an additional 27 per cent in the final three years. These annual growth rates may be adjusted if it is found that member countries are not complying with their obligations.

The integration of the sector into the GATT 1994 has not been without its problems. Thus, concerns have been raised about the back-loading of the integration process, the large number of safeguard measures in use, more restrictive use of rules of origin by the United States, tariff increases, the introduction of specific rates, minimum import pricing regimes, labelling and certification requirements, the maintenance of balance of payments provisions affecting textiles and clothing, export visa requirements, as well as the double jeopardy arising from the application of anti-dumping measures to products covered by the agreement.

Given that the textiles and clothing sector has been under restraint for some 40 years, some developing countries are concerned about the effects of the integration of the sector into the GATT 1994. For example, constrained exporters expect to loose some of the quota rents afforded by the MFA. Moreover, countries such as Bangladesh which had relatively large quotas, will now face stiffer competition from China. It can therefore be expected that there will be a major restructuring of the world textiles and clothing industry, unless the special safeguard measures or anti-dumping actions take the place of existing restraints. One aspect of the special safeguards is that it may be unnecessary during the integration process to invoke the exceptional provisions of Article XIX of the 
GATT for textiles and clothing products, but this could change when the integration is complete.

In the area of agriculture, the WTO agreement encompassed the elimination or tariffication of NTMs based on 1986-88 prices, the full binding of the new tariffs by developed and developing countries and phased tariff reductions, reductions in the level of domestic support measures (except for "green box" and de minimis amounts), and reductions in outlays on export subsidies and the volume of subsidized exports. The main exceptions to tariffication were rice and, for developing countries, some staple foods, where minimum access commitments apply. In addition, import licensing is still widely used, ostensibly as a sanitary and phytosanitary measure. Many countries also chose to introduce tariff quotas for a number of products, but these are not included as an NTM in Tables 5 and 6. In addition, some developing countries regard the prohibition of the use of variable levies not as an absolute ban but rather an admonition not to exceed bound levels where a variable charge is imposed, and these are also covered by the tables as Price Control Measures. ${ }^{1}$ However, domestic support measures and export subsidies are not covered in the tables, nor are special safeguards, triggered by increased import volumes or price reductions (by comparison with average 1986-88 prices expressed in domestic currency) which take the form of increased duties.

An indication of the importance of assistance in the area of agriculture can be obtained from the OECD (1998a and 1998b). As shown in Table 7, the overall level of support for the OECD countries, which now include some countries usually considered as developing or transitional economies, has shown a slow downward trend, with percentage Producer Subsidy Equivalents (PSEs) of intervention declining from 45 per cent in 1986-87 to 35 per cent in 1996. However, there are still quite significant differences in the level of support between countries and also between commodities (see OECD, 1998a for details). Although 1996 was the first year of implementation of the Uruguay Round results, OECD attributes much of the decline to reduced levels of market price support, caused by a rise in world prices, with little change in producer prices. While market price

1 The prohibition on certain measures is included in Article 4.2 of the WTO Agreement on Agriculture, and the list of specific measures, including variable levies, covered by the prohibition is in footnote 1 to the Article. 
support has fallen, it remains the principal form of support, but direct payment have become relatively more important. As a result of this shift to direct support, the percentage Consumer Subsidy Equivalents (CSEs), a measure of the implicit tax on consumers of agricultural policies, has also fallen from 37 per cent in 1986-87 to 24 per cent in 1996.

Overall, given the entrenched interests in agriculture, the WTO agreement was undoubtedly one of the main achievements of the Uruguay Round. Although some commentators, focusing on large volume, temperate zone commodities, have suggested that the tariffication process led to little increase in market access, the agreement brought the agricultural sector under more transparent rules and sets the stage for future, progressive liberalization of trade in the sector. However, it is also important to draw attention to the substantial tariff cuts for a wide variety of fruits, vegetable and tropical products.

Another feature of Table 5 is the relative importance of anti-dumping measures, particularly in the United States. As mentioned earlier, these became much more important when VERs started to be eliminated in 1992, and are now the principal form of contingency protection. It is expected that these will become even more important as other measures are phased out in the agriculture, textiles and clothing sectors. This is because many countries prefer anti-dumping actions over other forms of contingency protection: the injury test is lower (material injury cf. serious injury for safeguards), they allow discrimination against specific firms, there is a lower burden of proof (cf. countervailing measures), there is no adjustment requirement (cf. safeguards), they can be applied for a longer period (cf. safeguards) and there is no compensation requirement (Laird, 1999a). Moreover, it has also been found that even the opening of an antidumping investigation has a chilling effect on imports.

In the past, export performance requirements and local content requirements were used extensively in developed and developing countries, and these would have appeared as NTMs to the extent that they involved import restrictions. However, the WTO Agreement on Trade-Related Investment Measures (TRIMs) prohibits measures that (i) 
require particular levels of local sourcing by an enterprise (local content requirements); (ii) restrict the volume or value of imports which an enterprise can buy or use to the volume or value of products it exports (trade balancing requirements); (iii) restrict the volume of imports to the amount of foreign exchange inflows attributable to an enterprise; and (iv) restrict the export by an enterprise of products, whether specified in terms of the particular type, volume or value of products or of a proportion of volume or value of local production. Thus, such measures have now disappeared among the developed countries.

Some other important forms of trade measure are not reflected in either Table 5 or 6. These are technical barriers to trade (including sanitary and phytosanitary measures), state trading and rules of origin. As other forms of import protection have been reduced or eliminated technical barriers to trade are becoming increasingly important, particularly as sanitary and phytosanitary measures affecting agricultural products. Tensions concerning import controls related to the use of hormones are a prominent example of the testing of WTO rules in this area. In addition, we are now seeing the negotiation of mutual recognition agreements (MRAs), under which testing is recognized only for goods originating in the participating countries (the EU and the United States), not for third countries. Article XVII of the GATT on State Trading Enterprises has also begun to receive increasing attention (Davey, 1998). This is because of the important role that such enterprises play in agriculture: now that the sector has been brought more fully under the WTO rules with the completion of the Uruguay Round Agreement on Agriculture, any measure or procedure that could circumvent the commitments on export subsidies, market access and domestic support is being closely scrutinized. Another reason is the role that such enterprises play in the transition economies which are in the process of accession to the WTO.

Another gap in the coverage of Tables 5 and 6 is the absence of production or export measures which are still important in the agricultural sector for a number of OECD countries. If fixed producer prices, one of the main forms of support, are set higher than the world price plus the tariff, then importing is attractive and surpluses develop in the domestic market; export subsidies may then be used to dispose of these surpluses on the 
world market. Prior to the conclusion of the Uruguay Round, variable levies or quantitative restrictions were used to ensure that imports did not pose a serious threat to the supported domestic sector and these would have shown up as NTMs in Tables 5 and 6 and the existence of other forms of support and export subsidies could be inferred. However, in the post-Uruguay Round period these measures have been replaced by tariffs and sometimes tariff quotas, neither of which is included as an NTM.

Production subsidies still exist in the industrial sector of the developed countries, but under the WTO Agreement on Subsidies and Countervailing Measures (the "SCM Agreement") specific subsidies under three different categories are classified as: prohibited (red), actionable (amber), and non-actionable (green) subsidies (the "traffic Laird, 1999a). Export subsidies for manufactures are prohibited (red). Actionable (amber) subsidies, which includes production subsidies, are those that cause adverse effects (injury, nullification or impairment of benefits or serious prejudice) to a Member. Serious prejudice can be demonstrated on the basis of displacement of or impedance of exports into the subsidizing country market or a third-country market, significant price under-cutting, price suppression or depression, lost sales or an increase in the world market share of a primary commodity. ${ }^{2}$ Non-actionable subsidies include all non-specific as well as certain specific subsidies that involve assistance to industrial research and pre-competitive development activity, assistance to disadvantaged regions, and subsidies for environmental adaptation, so long as such subsidies meet certain criteria; such non-actionable subsidies can neither be challenged multilaterally nor countervailed. No overall, consistent quantitative estimates are readily available for OECD countries, 3 but evidence for GATT/WTO Trade Policy Reviews of these countries indicate a wide variety of state-aids for industry. However, further work is necessary to collect such information on a consistent basis, compatible with WTO definitions

2 A rebuttable presumption of serious prejudice arises in cases where the amount of the total ad valorem subsidy exceeds 5 per cent, or when subsidies are used to cover operating losses, or when there is direct debt forgiveness.

3 World Development Indicators publish data on transfers, but these do not correspond to subsidies within the meaning of the WTO agreement. 
On the whole, the developed countries do not use export taxes or export restrictions for commercial purposes, although the EZ has at times restricted grain sales to ensure supplies for animal fodder.

For developing countries, a major reform in trade policies took place from the mid-1980s, with some variation in dates. This was often associated with IMF/World Bank stabilization and structural adjustment lending operations. As part of the unilateral trade reforms and commitments in the Uruguay Round, developing countries and transition economies have shifted the emphasis from NTMs to tariffs, establishing a clearer linkage to international price movements. In addition, there is much less use of foreign exchange controls and import restrictions for balance of payments purposes; these have largely been abandoned as greater emphasis has come to be placed on macro-economic policies to solve what is essentially a macro-economic problem.

Today, the principal NTMs used by developing countries are similar to those used by the developed countries (Tables 8 and 9). The agricultural sector has a number of import licensing systems, mostly linked to the allocation of tariff quotas under the Uruguay Round tariffication. Also in agriculture, some countries still use variable levies and there are also some production and export subsidies. Other measures include: import/export quotas related to trade in textiles and clothing; local content and export balancing requirements (TRIMs), mostly in the automotive industry, but which were due to be phased out by the end of $1999 ; 4$ export subsidies to develop non-traditional manufactures, sometimes administered as tax breaks or subsidised finance (but direct subsidies have almost disappeared under fiscal pressures); and State-trading operations.

Developing countries are now also starting to make greater use of other NTMs which are generally consistent with WTO rules. For example, technical barriers to trade, including sanitary and phytosanitary controls are now being used more by developing countries, and in this they are also starting to approximate the use of such measures by the developed 
countries. Other measures include prohibitions on the importation of pornography, arms and munitions, etc.

Among the more worrying trends is the increasing adoption of anti-dumping measures by developing countries (Table 10). Thus, Miranda, Torres and Ruiz (1998) note that "new users" (those which began conducting anti-dumping investigations in the 1980s) now conduct 54 per cent of all anti-dumping investigations by WTO Members, compared with 12-21 per cent in the 1987-92 period. Mexico is the most frequent user, followed by Argentina, Brazil, South Africa, India and the Republic of Korea. It is sometimes argued that the increased use of anti-dumping procedures is the price to pay for the greater openness of developing countries' economies, but a number of concerns have been expressed about the legitimacy of the use of anti-dumping measures, including the conduct of investigations: in essence, anti-dumping is being used not against predatory dumping or even "unfair" trading practices of foreign firms, but rather to protect the entrenched position of oligopolistic firms in the iron and steel, chemicals industries, etc. It has also been observed in several countries that there is a correlation between the level of economic activity and anti-dumping investigations.

Miranda, Torres and Ruiz (1998) also indicate that developing countries are more targeted by developed countries' anti-dumping actions than other countries; moreover, they are often the target of such actions by other developing countries.

This trend in the use of NTMs against imports by developing countries also marks a trend towards a level of discrimination that did not exist in the past. For example, UNCTAD (1990) noted that NTMs used by developing countries were on the whole nondiscriminatory. In a study of some 50 developing countries, UNCTAD concluded that most NTMs were of a general nature, not pointed at individual suppliers. The NTMs involved were import licensing, advanced import deposits and central bank authorizations. 
Some developing countries also apply export taxes on foodstuffs and other materials for use in domestic processing industries, e.g. oil seeds, tropical timbers, raw hides and skins, etc. Quantitative restrictions on exports have mainly been replaced by export taxes. In general, quantitative restrictions are prohibited under Article XI of the GATT. However, as noted by Laird (1999a), certain exceptions to this general prohibition are allowed. For example, under Article XI:2 of the GATT temporary prohibitions or restrictions are allowed to relieve critical shortages of foodstuffs. Article XX on General Exceptions also allows the use of export restrictions in certain circumstances, including those applied under the Convention on International Trade in Endangered Species (CITES). Subparagraph (g) allows exceptions relating to the conservation of exhaustible natural resources provided that such measures are made effective in conjunction with restrictions on domestic production or consumption. This provision has been used, inter alia, to justify restrictions on the export of tropical timbers. Moreover, sub-paragraph (h) may provide cover for export restrictions undertaken in pursuance of obligations under intergovernmental commodity agreements. The WTO Agreement on Technical Barriers to Trade also makes it clear that a member may take measures "necessary to ensure the quality of its exports". Under Article XX (I), a WTO Member may restrict exports of domestic materials necessary to ensure essential quantities of such materials to a domestic processing industry during periods when the domestic price of such materials is held below the world price as part of a governmental stabilization plan. Such restrictions are only allowed if they do not result in an increase in the exports of or the protection afforded to the domestic processing industry, hence the switch to the use of export taxes to achieve such goals.

\section{Services}

Available data on trade in services are weak compared to those for merchandise trade, and cross-country data on the magnitude of barriers to trade in services do not exist. Since tariffs are not applied to such trade (although conceptually one could imagine some kind of tax on the consumption of foreign services which would work like a tariff), the main forms of intervention are prohibitions, quantitative restrictions (QRs) and discriminatory practices affecting cross-border supplies, foreign commercial presence and movements of individual suppliers; they may be accompanied by domestic regulatory barriers in individual markets. Private sector associations may also have a role in defining 
"sound" practices, etc. Thus, foreign firms may be prohibited from the provision of certain services, QRs may apply to the value or quantity of specific services or to the number of firms allowed to contest a particular market. There may be licensing and qualification requirements relating to consumer protection, prudential supervision, pricing, and so on. The reservation of certain segments of services markets to the State is quite common, although this has been much reduced in recent years.

Many governments set limits or conditions on foreign direct investment (FDI), perhaps the most important mode of supply of services. For example, FDI may be limited to less than a controlling interest, e.g. less than 50 per cent of total or equity shares. In cases such as joint ventures or industrial collaboration arrangements, special terms for foreign investment may imposed by the host Government. Controls may be imposed on the royalty payments or the repatriation of profits; there may be limits on sales of assets, perhaps to discourage footloose industries (Laird, 1999b). Terms may also include local content requirements, export-performance requirements, a need to use local labour or upgrade local management, technology requirements, etc. The host Government may set limits to patents on products and/or processes.

On the other hand, some governments promote FDI by offering a variety of incentives, including tax holidays, tax exemptions, tax rebates, etc. as well as protection or industry assistance. Such incentives, which are not currently the subject of GATS disciplines, can dissipate the benefits of FDI, and the costs and benefits of promotional policies, may not be transparent. This opacity makes it difficult for taxpayers and other countries to know how much protection is being afforded and what are its effects. As Guisinger (1987) notes: "It is doubtful that governments ever know the exact tax or subsidy on firms achieved by investment policies. But the great variety of policy instruments and the proliferation of investment-screening agencies with discretionary powers suggest a strong desire to intervene in a discriminating fashion rather than to remain passive providers of protection."

The principal source of information about intervention in the services sector are the GATS schedules of WTO Members (plus China which participated in the Uruguay Round 
although not yet a WTO Member), although like tariff bindings they represent a commitment and in a number of cases markets are more open in practice. In a positive list, the schedules contain specific commitments in respect of market access and national treatment, structured by one of the four modes of supply covered by the GATS (crossborder, movement of the consumer to the service-supplier abroad, commercial presence, and temporary movement of natural persons). Concerning market access, the GATS prohibits limitations on the number of service suppliers allowed, the value of transactions or assets, the total quantity of service output, the number of natural persons that may be employed, the type of legal entity through which a service may be supplied and the level of participation of foreign capital. If a WTO Member maintains any of these restrictions, it must be listed in its schedule of specific commitments. The coverage of MFN treatment accorded by WTO Members is determined by a negative list of services which are exceptions to the application of the MFN rule, mostly invoked because of concerns about the adequacy of offers by other countries or to "grandfather" pre-existing bilateral arrangements in individual sectors. 5 The sectors particularly affected by such exemptions are the various transport sectors and audio-visual services.

Although the sectoral commitment of the GATS Members are essentially qualitative, Hoekman (1995) provides a number of quantitative estimates of the extent to which measures are bound and the share of such sectors where the binding relates to free trade. Some of this information is reproduced in Tables 11 and 12. The indicators, which are similar to frequency coverage ratios sometimes used to describe the prevalence of NTMs for goods, give some indication of the degree of openness in cases, particularly in sectors where the Members have made market access and national treatment commitments without limitation. Hoekman makes the point that most commitments undertaken in services in the Uruguay Round are of a standstill nature, i.e., they amounted to promises not to become more restrictive than at the time of the negotiation. It is also recalled that some countries sectors are already more open than the commitment in their schedules.

5 This negative list approach contrasts with the NAFTA and proposals for a Free-trade Area for the Americas, in which a positive list approach is used, identifying sector to be covered. 
Table 12 gives an overview of the Uruguay Round commitments (i.e., excluding the results of the extended negotiations on basic telecommunications and financial services) by three major country groupings: (i) the high income countries, comprising OECD countries plus Hong Kong, China; the Republic of Korea; and Singapore; (ii) all other GATS Members; and (iii) a subset of (ii), being a group of large developing countries (Argentina, Brazil, Chile, China, Colombia, India, Indonesia, Israel, Malaysia, Pakistan, the Philippines, Poland, South Africa, Thailand and Venezuela). Four indicators are reported: (i) the share of sectors where a commitment was made; (ii) the weighted average coverage of the commitments, adjusted for qualifications; (iii) the share of sectors where commitments include no exceptions or qualifications on national treatment or market access (no restrictions) relative to a Member's total commitments; (iv) the share of "no restrictions" relative to the 155 possible sectors of the GATS classification list. The higher the ratio, the more liberal the country. As Hoekman states, the indicators show that GATS Members as a whole are still a long way from free trade in services, and developing countries have made substantially fewer commitments than the high-income countries.

\section{LIBERALIZATION STRATEGIES}

\section{A. MARKET ACCESS}

The basis objectives of the WTO is freer (not necessarily free) trade and the need for predictable international trading relationships. Intervention is allowed within the rules agreed by consensus. However, while average industrial tariffs have fallen, most NTMs eliminated and clearer rules now govern international trade, the preceeding review of protection shows that there is still considerable scope for further liberalization and for greater transparency and predictability in the use of trade measures. On tariffs alone, it has been estimated that a 40 per cent reduction in tariff protection in manufactures would yield approximately US\$70 billion in global income (welfare) gains in 2005, while the potential gains from similar cuts in agricultural tariffs would add US\$ 60 billion (and another US $\$ 10$ billion from similar cuts in subsidies (Hertel, Anderson, Francois, Hoekman and Martin, 1999). It is also estimated - albeit more tentatively - that liberalization in the services sector would produce welfare gains of as much as $\$ 332$ billion in 2005 (ibidem). In absolute terms, developing countries would gain more from 
the industrial tariff cuts, but they would gain more in proportion to their production from the liberalization in the agricultural sector. Thus, tariff negotiations in agriculture and manufactures still have considerable potential for increasing welfare, although at the time of writing it had not yet been decided to conduct market access negotiations in industrial tariffs. However, the built-in agenda will tackle NTMs in the built-in agriculture and services negotiations on market access as well as in the agreed review of implementation of WTO rules.

As a general proposition, trade liberalization increases economic welfare unless protection is associated with externalities, and government intervention, whether in the form of tariffs, subsidies or other means, is associated with a national welfare loss. For example, there is now clear evidence that the promotion of import-substitution industrialization caused considerable harm to the agricultural sectors and increased rural poverty in many developing countries. Intervention in the rural sector has also been mismanaged, badly targeted and costly. Thus, it is generally desirable to move towards less intervention in developed and developing countries alike. However, strategically, some countries believe that reciprocal or multilateral agreements have the advantage over unilateral liberalization in terms of selling a reform to domestic lobbies, and that a progressive reform, while more costly, minimizes political risks in the short term.

Nevertheless, there are some important questions about the best approach to liberalization, even on a multilateral basis. For example, it can be shown from simple analysis of effective rates of protection that distortions and, hence, welfare losses can be increased by liberalizing sectors with low levels of protection. 6 Thus, effective protection can be increased by reducing protection on inputs while leaving the duty on finished goods unchanged, and this effect is exacerbated the higher the materials/output ratio in production. This is not merely a matter of theory: Dee, Hardin and Schuele (1998), in an

6 Effective protection is the protection afforded to value added in production processes, resulting from the combined effects of protection on materials inputs into the process and protection on the outputs. It can be given by the formula: $\mathrm{g}=((\mathrm{Df}-\mathrm{X} . \mathrm{Dm}) /(1-\mathrm{X}))$ where $\mathrm{g}$ is the effective rate, Df is the tariff rate on outputs, $\mathrm{Dm}$ is the rate on material inputs, $\mathrm{X}$ the materials-output ratio at free trade prices, adjusted by the formula $\mathrm{X}=\mathrm{X}^{\prime} *((1+\mathrm{Df}) /(1+\mathrm{Dm}))$, where $\mathrm{X}^{\prime}$ is the observed materials-output ratio under protection. Protection can be measured by tariffs or tariffs and NTBs. 
analysis of APEC's proposals for Early Voluntary Sectoral Liberalization (EVSL), show that partial liberalization can lead to economic welfare losses, particularly where relatively low-protected upstream sectors are liberalized and more highly protected downstream processing sectors remain protected. Concerning services, these are often inputs into the production, transport and marketing of goods. Where protection or other forms of intervention in services is lower than for the goods the services are used to produce, reduction of such protection can increase protection for the production process, but where the services protection is higher, then liberalization of the services sector can help eliminate or compress negative effective protection for the production process.

The problem is that it is very difficult to be precise about the overall level of trade intervention in goods and services. In any particular case, tariffs may be clear, although, as we have seen, sometimes it is also difficult to be sure about tariff treatment. But to estimate the combined effect of all barriers in all sectors requires some heroic assumptions. ${ }^{7}$ Yet, without taking both tariffs and NTMs across the goods and services sectors into consideration estimates of the effects of protection and liberalization could be quite erroneous (Deardorff and Stern, 1985). Nevertheless, it is possible to state some stylized facts about the general tendencies and to establish some procedures for liberalization that would tend to be welfare increasing.

An approach which would resolve procedural issues would be to opt for complete trade liberalization as has been proposed by Fred Bergsten and others. However, this would cut deeply into sensitive sectors in the industrial countries, and many developing countries still rely on tariffs for revenue purposes, although they are making determined efforts to shift the burden of revenue-raising onto domestic indirect taxes. In addition, this would also require equivalent efforts in domestic supports and export subsidies in agriculture, otherwise there would be a growth of surpluses to be dumped onto world markets.

7 Deardorff and Stern (1996) make an estimate of the redistribution effects of a 25 per cent reduction in the incidence of barriers to trade in services, using the "guesstimates" (sic) computed by Hoekman (1995) which are reproduced in Tables 12 and 13 of this paper. 
Short of agreeing on complete trade liberalization, the approach which would seem to address best the issues of tariff peaks, tariff escalation and which would lead to a general reduction and compression of effective rates of protection would be a formula approach, such as the Swiss formula used in the Tokyo Round. This would also be an advantage to smaller countries which have little negotiating power, so that their requests tend to be of little interest to the larger trading countries. Other methods include: request and offer, zero for zero, or a mixture of these various approaches. ${ }^{8}$ The compression power of the Swiss formula can be seen from Chart 1 , which compares a linear cut of 50 per cent with the Swiss formula with the coefficient value of 14.9 While this would not necessarily exclude exceptions, the history of the Tokyo Round was that such exclusions tended to be focused in areas of export interest to the developing countries. The impact of such exceptions could be reduced by using a minimum cut for each tariff line, but, if exceptions are to be allowed, it would be preferable to allow a backloading of the implementation to allow more time for sensitive sectors to adjust, rather than allowing deviations from the formula. The formula could also be varied, for example, by increasing or reducing the coefficient to give shallower or deeper cuts if so desired. The danger of the zero for zero approach is that it tends to be focused on products which already have low protection and such partial liberalization can lead to economic welfare losses, as noted in the Dee, Hardin and Schuele (1998) analysis mentioned earlier.

The usefulness of the harmonizing approach extends to, indeed is, also applicable to a global analysis of protection in which other countries also use sectoral interventions and these are sufficient to affect world prices, or the terms of trade. For example, if high levels of intervention in a sector in one country are matched by similar intervention abroad, then the combined effects will be to reduce world demand for the good and thus reduce its price both at home and abroad, i.e., the terms of trade. That is, if high levels of intervention are correlated internationally, then high intervention may be associated with low protection rather than high. 10 Empirically, this effect has been found to be most marked in the textiles, clothing and footwear industries (Deardorff and Stern, 1985). In

8 For further details, see Laird (1998).

9 The Swiss formula is given by $T_{1}=a T_{0} /\left(a+T_{0}\right)$. In the Tokyo Round, the coefficient, a, was generally set at the value of 14 .

10 This analysis was originally for tariffs by Deardorff and Stern (1985). 
such cases, liberalization by an important block of countries could affect the terms of trade and increase the protective effect of regimes in countries which do not liberalize.

On the other hand, for some goods, liberalization may lead to increased international prices, e.g., some subsidized agricultural commodities. Deardorff and Stern (1996), in a global analysis of liberalization of trade in goods and services note that positive welfare gains are not inevitable for all countries when trade is liberalized, because the terms of trade for any one country could deteriorate if its import prices rose and its export prices fell, but they also note that these effects tend to be small. They also note that under their simulation scenarios, with equivalent liberalization in goods and services, services would expand in some countries and contract in others. The effects of services liberalization on goods depends on whether the two are complements or substitutes.

These complex interactions tend to reinforce the point that, to sell a liberalization package, it is desirable to move multilaterally to remove intervention simultaneously across sectors in a manner which compresses the spread of intervention. Theory and empirical research both point to the importance of taking a comprehensive approach, tackling tariffs and NTMs across all sectors and countries in a systematic manner. Thus, procedures for liberalization should be focused on a top down approach, "lopping the tall poppies". All in all, a formula approach, adopted multilaterally, without giving way to special pleading and carve-outs for highly protected sectors, allows governments to portray domestic liberalization as a quid pro quo for improved access to foreign markets. This should not prevent individual countries from pursuing their own reform programmes, but suggests that strategically the binding of such autonomous reforms should be the objective in multilateral negotiations, rather than holding off making concessions (liberalization) that might not draw forth equivalent concessions from trading partners.

This brief discussion of theory points clearly to the importance of including manufactures in the market access negotiations for a new round. As noted earlier, developing countries in particular have a major stake in liberalization of trade in manufactures, since the larger share of the gains from liberalization of such trade would accrue to the developing countries from global liberalization in the sector (Hertel, Anderson, Francois, Hoekman 
and Martin, 1999). This derives from the fact that their exports of manufactures have been increasingly dramatically, from some 28.8 per cent as a share of total exports in 1980 to 66.6 per cent of the total in 1995 (UNCTAD, 1999). In addition, developing countries have now become important markets for their own exports of manufactures: in 1990 developing countries' exports of manufactures to other developing countries was 37.2 per cent of their total exports of such products, and this share rose to 43.1 per cent in 1995 (UNCTAD, op.cit.).

The importance of manufactures liberalization for developing countries is also evidenced by a joint UNCTAD-WTO study (UNCTAD-WTO, 1998) which shows that in a number of sectors with a relatively high value added and technological content annual export growth of the developing countries in the period 1990-95 was 15 per cent, compared with 9.6 per cent for their exports as a whole. However, this performance is highly influenced by the exports of a small number of major developing country exporters of manufactures. The dynamic exports were those that faced the lowest tariff barriers, while much lower export growth was achieved where tariffs were higher. At the lower end of the development process, lower-income countries and the least-developed countries have a major interest in agricultural products and products with low value added and technological content (textiles, clothing, footwear and leather products), areas where market access barriers are highest.

Proposals for accelerated tariff liberalization in eight industrial sectors (chemicals, energy and energy equipment, environmental products, gems and jewellery, fish and fish products, medical and scientific equipment and toys) have been proposed by APEC, which was unable to agree on liberalization within these sectors at the APEC summit in July 1999, and referred the idea to the WTO in the hope of an early harvest before the Seattle Ministerial meeting. The idea was developed out of an APEC proposal for Early Voluntary Sectoral Liberalization. However, the EU rejected the notion of any tariff deal outside the context of a wider set of negotiations, ${ }^{11}$ and the opening of negotiations in industrial products remains a matter of uncertainty. On the other hand, the EU supports the idea of tariff and quota-free access for essentially all products from the least- 
developed countries (WTO document WT/GC/W/178), and this seems to be attracting support for unilateral action despite the failure of Seattle.

Apart from the general approach to liberalization, there are also a number of other technical questions to be addressed in relation to tariff negotiations and which also have a bearing on the level of market access. For example, one important decision relates to the selection of the base period or base rates for negotiated liberalization and the implementation period for the tariff cuts; one radical suggestion might be to work on the basis of current applied rates, rather than bound rates, to ensure that the tariff cuts will provide meaningful liberalization, instead of merely reducing the gap between bound and applied rates. The averaging technique is also important: in industrial products importweighted averages are normally used, but this allows lower cuts on items with high protection (and, hence, lower trade weights), unless minimum cuts are agreed for each tariff item, as was done in the Uruguay Round, often for the more sensitive, highly protected items. Simple averages were used in the agricultural sector in the Uruguay Round, where there were insufficient data to allow the use of weighted averages and simple averages were used.

Balanced market access negotiations would also need to tackle the use of NTMs in goods and services. However, NTMs are difficult to quantify, but studies point to the facts that they are costly to administer, costly to consumers, costly to exporters (in terms of lost trade), inefficient ways of creating jobs, lack transparency, are inherently discriminatory, and are most intensively used against developing countries and transition economies (Laird, 1998). Moreover, in isolating domestic industry from international competition, domestic firms are relatively unaffected by price trends on world markets and have little incentive to adopt new technologies or modern business practices.

In the built-in agenda, the market access aspect of NTMs will mainly be covered in the negotiations in agriculture and services, while other aspects will be covered in the review of the operation of the WTO agreements, as discussed later. 
In agriculture the NTM aspect of the negotiations will encompass the elimination or the expansion of tariff quotas and perhaps a discussion on the manner of their allocation. The negotiations will also discuss the elimination or relaxation of remaining domestic supports, and negotiations are likely to focus on a further reduction in the Aggregate Measure of Support (AMS) which in the Uruguay Round is being reduced by 20 per cent vis-à-vis the 1986-88 base period, excluding green box and blue box measures which were exempt from the reductions. Since the Uruguay Round commitment was in terms of overall spending, it might also be expected that exporters would also want to see some limitations on inter-sectoral shifts in funding, comparable to the minimum cuts per tariff line in the tariff negotiations. There are also likely to be efforts to further reduce the scope for the use of market price supports to limit further or even eliminate any linking of supports to production levels.

While a number of agricultural exporters, such as Argentina and Australia, would like to see the elimination of export subsidies, the main question to be resolved will be the extent of the reduction in their use. In principle, this could take place in the context of negotiations on rules leading to the alignment of rules on domestic supports for agriculture with those for manufactures. However, the more likely scenario is for some further rolling back of support through extended volume and budget commitments, including limiting the scope for inter-sectoral shifts in subsidies. There may also be an attempt to ratchet down subsidies by limiting the scope for building up credits in unused subsidies when prices are high. It is also likely that there will be some further discussion of the scope of "green box", "blue box" or "S\&D box" exemptions, all of which are technically rules negotiations with implications for market access.

Market access negotiations in services, which started in February 2000, are part of the built-in agenda of the WTO (Article XIX of the GATS) and will address MFN exemptions, which were, in principle, to last no longer than ten years. In relation to these renegotiations and any expansion of specific commitments, the absence of customs tariffs or easily quantifiable NTMs makes it difficult to negotiate on expanded market access through the progressive reduction of intervention in services trade. This is why, beyond 
discussion of how GATT concepts of MFN and national treatment could be applied to trade in services, the Uruguay Round and subsequent sectoral negotiations focused on achieving a degree of intra-sectoral reciprocity (Hoekman and Kostecki, 1995). However, to the degree that it is possible to compute a price wedge associated the supply of services, then one option for future market access negotiations in services would be some form of tariffication (or indirect taxation on foreign providers), as in the Uruguay Round agricultural negotiations (Snape, 1994). This may prove possible in areas where standardized services are provided, e.g., basic telecommunications or banking services. Even in these areas some questions remain, such as how to control for the risk premiums required in certain markets or for the additional costs associated with universal service obligations. It is also possible to think about other automatic or formula approaches, or about a system of benchmarks to be applied across all Members. One possibility would be to start with the generally more ambitious commitments undertaken by the six countries that have undertaken since the establishment of the WTO, although no doubt this would be resisted by certain developing countries.

In principle, the sectoral approach should encourage countries to make offers to liberalize in order to obtain the benefits of their own liberalization. Given the key role that services plays in the production, transport and marketing of their goods exports, one would imagine that they would have been anxious to ensure that they could obtain services at world prices. However, in the Uruguay Round, a number of developed and developing countries placed great emphasis on ensuring that there was reciprocal liberalization in key markets, and finding such a balance in narrowly defined sectoral negotiations in services is difficult. Moreover, a number of developing countries, in particular, remained concerned about the perceived effects of opening up to foreign direct investment, which is estimated to be the principal mode of supply (Hoekman and Kostecki, 1995), and, initially, did not even want services to included in the Uruguay Round. As a result, the specific commitments leave most of production and trade in services unbound even where it is already liberalized, as discussed above.

The issue of the treatment of foreign direct investment (commercial presence) is much less emotive than some years ago, with many developing countries now actively 
promoting foreign direct investment to capture associated technology gains and market access, and thus accelerate their own development and integration into the world economy. However, a number of countries still place great emphasis on being able to impose conditions on inward foreign direct investment and the provision of support for investment by domestic firms. This attitude continues to block efforts to adopt a comprehensive framework for international investment, such as the Multilateral Agreement for Investment. ${ }^{12}$ However, it is inevitable that this issue will be somewhere on the agenda for future multilateral negotiations in some guise or other.

Nevertheless, given the structure of the GATS with the scheduling of commitments on the basis of mode of supply and sectoral specific commitments, it seems likely that further negotiations in the services area will again be sectoral, driven by vested interests in Member states (Hoekman and Kostecki, 1995). This implies attempting to achieve a balance of concessions in a situation where the weight of import-competing sectors greatly exceeds that of export interests. On the other hand, given the inclusion of commercial presence as a mode of supply, labour interests may see foreign investment as job-creating, or at least providing alternative employment opportunities, and be less opposed to liberalization than in the goods area. It has been suggested that regulatory agencies have a vested interest in maintaining their positions which could be weakened by the presence in their markets of firms located in foreign jurisdictions, and this would also lead government to favour commercial presence.

The bulk of experience of recent years is that FDI brings important advantages through new technologies and enhanced access to overseas markets, stimulating production and trade. Foreign investment, like domestic investment, increases income and employment in the process of capital formation and in due course increases capacity to reach even higher income levels after capital has been formed. The gains from trade liberalization can be enhanced by allowing investment to pursue the more efficient production capabilities from comparative advantage (and hence achieve also the increased consumption possibilities associated with trade). If markets are functioning efficiently, foreign investment, like foreign trade, increases global economic welfare and can also eventually help to equalize 
the returns to the different factors. With appropriate pricing and regulatory policies, many of the fears of FDI are proving unjustified. It is therefore important to generate further information on these effects to foster an atmosphere which will favour liberalization.

Of course, there will still be the dilemma between the desire to gain the benefits of domestic liberalization and obtaining reciprocity. In this respect, one difficulty is that developing countries, which were interested offering the supply of labour found that in the Uruguay Round this mode of supply remained largely restricted, except for humancapital intensive segments and movements directly related to commercial presence. No doubt this issue would also re-emerge in a new round. Drawing the developing countries more fully into future negotiations is also complicated by the provision in Article XIX:2 of the GATS which grants "appropriate flexibility for individual developing countries for opening fewer sectors, liberalizing fewer types of transactions, progressively extending market access in line with their development situation and, when making access to their markets available to foreign service suppliers, attaching to it conditions aimed at achieving the objectives referred to in Article IV" (of increasing participation of the developing countries in world trade). This would appear to give developing countries scope for limiting their offers, but the experience of the Uruguay Round in the goods areas and subsequent sectoral negotiations in telecommunications and financial services suggests that there will be considerable pressure on the developing countries to participate with substantive offers.

\section{B. TRANSPARENCY}

As discussed in Section II, conditions of market access could be made more secure and transparent even in the tariff area, and this would have the advantage of clarifying the conditions for trade and investment. Increased transparency would also reduce the difficulties of making quantitative estimates of the levels of protection at the national and global levels. There is a need for greater simplification of tariff structures, transparency or limitations on the use of different tariff types, such as tariff quotas, specific and mixed rates, and so on. Consideration might also be given to setting conditions on the use of specific and compound rates as well as tariff quota administration, although if the use of 
such rates were prohibited then greater use might be made of anti-dumping duties as a form of contingency protection. Information should be made public on preferential and concessional rates, together with the relevant trade flows, as well as the application of other charges. Transparency would also be enhanced if an effort were made to simplify tariff structures to a uniform rate, for revenue purposes, or few broad bands, where industrial policy dictates. Consideration might also be given to limiting tariffs to the sixdigit level for statistical reporting of trade. It might also be agreed to establish value for duty only on an FOB (eliminating the option of a CIF) basis, which would also reduce the level of protection as well as transparency of the ad valorem incidence on the good itself. However, the need for information is greatest in the area of services where a consistent, detailed reporting requirement is necessary as a precursor to work on estimating the effects of intervention.

Simplification of rules of origin and accumulation would also increase transparency and reduce the risk of preferential rules being used for protection purposes. Tests such as change of tariff heading or a (varying) percentage of domestic value added are intended to simplify the computation of value for duty, but most countries use a mixture of such rules and these even vary for the same product in different agreements. These could be simplified by a single approach such as change of tariff heading. A more radical approach would be to charge duties according to the value added in countries which get different tariff treatment, but the complexity of the calculations and the scope for fraud make this an unlikely option. Certainly, there is a need for WTO disciplines in this area.

Finally, there is a need for greater transparency in the use of other charges on trade. An effort might be made to ensure that these are based on the cost of the service and not simply an additional ad valorem charge for revenue purposes. Similarly, there is a need to tighten the application of national rules which allow indirect taxes to differentiate between domestic and imported goods by modifying descriptions of products that are close substitutes in consumption.

The services negotiations will also suffer from the lack of information on production and trade on the various sectors and sub-sectors, particularly those which are not covered by 
specific commitments, as well as from the lack of information on the quantitative significance of the various forms of intervention in the sector, and, hence, also from the direct and indirect effects of such intervention. Such information is often useful to build lobbies in favour of liberalization when domestic firms can see clearly how they are penalized by the prices they pay for the inputs of services.

\section{RULES ISSUES}

In the built-in agenda, the review of the operation of the WTO Agreements offers the best possibility for any tightening of disciplines on the use of NTMs, although the review per se does not absolutely guarantee negotiated changes in the rules. The rules discussions are expected to cover anti-dumping, countervailing and safeguard measures, technical barriers, TRIPS, rules of origin, government procurement, most of which have important implications for market access.

One of the key areas is the use of contingency protection. As mentioned earlier, the WTO Agreement on Safeguards allows for some discretion in the allocation of quotas, but so far there has been no major surge in the use safeguard measures under Article XIX. The main area of contingency protection has been anti-dumping, except in the textiles and clothing area where special safeguards under the Agreement on Textiles and Clothing have also been widely used. When this sector is fully integrated into GATT 1994, there may be an increase in the use of safeguards under these provisions of the Safeguards Agreement, but it is equally possible that the strain will be taken up by antidumping mechanisms. This could also arise from the progressive liberalization of the agricultural sector. However, so far, it is difficult to envisage a reopening of the Safeguards Agreement which is largely untested. On the other hand, it is the Safeguards Agreement which prohibits the use of VERs and, from press reports, this is an area where it is evident that a number of measures are still being negotiated between governments, e.g., in the iron and steel and automotive sectors. Similarly, there are a number of product areas, such as petroleum and aluminium where production quotas fulfil the role of export restraints. Again, price undertakings as a negotiated outcome of anti-dumping cases have similar effects to VERs; this seems inconsistent and may be worth examining. It might be useful to examine whether a single set of rules on contingency protection, 
allowing legalized backsliding over an adjustment period, could be developed to encompass anti-dumping, countervailing, safeguards and the various special safeguards provisions. A linkage to competition policy ideas could also be beneficial.

Two other areas deserve special mention. First, government procurement is one of the few exceptions to the Single Undertaking of the Uruguay Round. In this area efforts have focused mainly on increasing the transparency of procurement procedures, rather than access negotiations as such. In addition, the issue of whether some rules on competition policy should be part of the WTO is currently being discussed, but the issue in complicated by possible cross-linkages to anti-dumping.

Rules negotiations will also form part of the forthcoming services negotiations. The GATS is a major achievement in bringing services trade under multilateral disciplines, but it is only the first step in this direction and there is much more to be done. Indeed, this is recognized in GATS Article VI which calls for continued negotiations in order to fill the general disciplines on domestic regulation with actual content, and negotiations on safeguards, subsidies and procurement in services are still under way. At the broadest level, consideration might be given to re-establishing the GATS along the lines of the more general approach used in the EU, NAFTA and ANZCERTA, with a negative list approach and making national treatment an obligation (Hoekman, 1996), although this is probably unrealistic. There is a need for tightening disciplines in some areas: for example, in contrast with GATT rules on goods, the GATS imposes no disciplines on subsidies subject to the national treatment constraint with regard to alternative suppliers or services, and even this may be subject to limitations. In recent rounds of GATT negotiations, a concern was to ensure that the expected benefits of negotiated tariff reductions were not undermined by the use of non-tariff measures. This explains the tightening of disciplines on the use of subsidies under the SCM Agreement and the Agreement on Agriculture; but in services there are no similar constraints. Again, consistent treatment of safeguards and government procurement could usefully be addressed, and, in general, the development of a consistent set of disciplines in goods and services should be an agenda items for the new round. 
In services, the need for rules on competition and regulatory policy is even more pressing than in the case of goods because the prevalence of state or private monopolies and oligopolies in services effectively debases the value of market access and national treatment commitments. 


\section{REFERENCES}

Brown, D., A. Deardorff and R. M. Stern (1995), "The liberalization of services trade: potential impacts in the aftermath of the Uruguay Round" in Martin and Winters (1996).

Crawford, J.A. and S.Laird (2000), "Regional Trade Agreements and the WTO", paper presented at North American Economics and Finance Association meeting, Boston 6-9 January 2000 (AEA-ASSA Annual Meetings).

Daly, M. (1998), "Investment Incentives and the Multilateral Agreement on Investment", Journal of World Trade, Vol. 32 No. 2 (April).

Davey, W. J. (1998), “Article XVII GATT: An Overview”, mimeo. WTO, Geneva.

Deardorff, A. and R. M. Stern (1985), "The structure of tariff protection: Effects of foreign tariffs and existing NTBs", The Review of Economics and Statistics, Vol. LXVII No. 4 (November).

Dee, P., A. Hardin and M. Schuele (1998), "APEC Early Voluntary Sectoral Liberalisation", Productivity Commission Staff Research Paper, Ausinfo, Canberra,

Drabek, Z. and Laird, S. (1998), "The New Liberalism - Trade Policy Developments in Emerging Markets", Journal of World Trade, Vol. 32 No. 5 (October).

Francois, J. and B. McDonald (1996), “The Multilateral Agenda: The Uruguay Round Implementation and Beyond", Staff Working Paper RD-96-012, Geneva: WTO.

Guisinger, S. (1987), "Investment Related to Trade" in J. M. Finger and A. Olechowski (eds.), The Uruguay Round: A Handbook for the Multilateral Trade Negotiations, The World Bank, Washington D.C.

Hertel, T., K. Anderson, J.F. Francois, B. Hoekman and W. Martin (1999), "Agriculture and Non-agricultural Liberalization in the Millennium Round", paper presented at The Conference on Agriculture and the New Trade Agenda in the WTO 2000 Negotiations, held in Geneva on 1-2 October 1999.

Hoekman, B. and M. Kostecki (1995). The Political Economy of the World Trading System, Oxford University Press, Oxford. 
Hoekman, B. (1995), "Assessing the General Agreement on Trade in Services" in W. Martin and L. A. Winters, "The Uruguay Round and the Developing Economies", World Bank Discussion Paper No. 307, Washington D.C..

Hoekman, B. (1996), "Assessing the General Agreement on Trade in Services" in Martin and Winters (1996).

Laird, S. (1997), "Quantifying Commercial Policies" in Joseph F. Francois and Kenneth Reinert, Applied Trade Policy Modelling: A Handbook, Cambridge University Press, Cambridge.

Laird, S. (1998), "Multilateral Approaches to Market Access Negotiations", Paper prepared for a conference on Multilateral and Regional Trade Agreements: An Analysis of Current Trade Policy Issues, organized by the OAS, WTO and Georgetown University, and held in Washington D.C. on 26-27 May 1998.

Laird, S. (1999a), "Export policy and the WTO", Journal of International Trade and Economic Development, Vol. 8 No. 1, pp. 73-88 (March 1999).

Laird, S. (1999b), "Transition economies, business and the WTO", World Competition, Vol. 22 No. 1, pp. 171-187 (March 1999).

Laird, S. and A. Yeats (1990), Quantitative Methods for Trade Barrier Analysis, MacMillan, London and New York University Press, New York, N.Y.

Low, P. and A. Yeats (1994), "Non-tariff Measures and Developing Countries", Washington D.C.: World Bank Policy Research Working Paper No. 1353.

Martin, W. and L. A. Winters (1996), The Uruguay Round and the Developing Countries, Cambridge University Press, Cambridge, Great Britain.

Michalopoulos, C. (1999), "Trade Policy and Market Access Issues for Developing Countries", mimeo. Development Division, World Trade Organization.

Miranda, J., R. A. Torres and M. Ruiz (1998) “The International Use of Anti-dumping: Journal of World Trade, Vol. 32 No. 5, pp. 5-71 (October).

OECD (1997), Indicators of Tariff and Non-tariff Trade Barriers, Paris.

OECD (1998a), Agricultural Policies in OECD Countries - Monitoring and Evaluation, Paris. 
OECD (1998b), Agricultural Policies in OECD Countries - Measurement of Support and Background Information, Paris.

Snape, R. (1994), "Principles in Trade in Services", in The New World Trading System: Readings, OECD, Paris.

UNCTAD (1990), Trade Expansion among Developing Countries: Constraints and Measures to overcome them, TD/B/1260, Geneva.

UNCTAD (1999), Handbook of International Trade and Development Statistics 1996, 1997, United Nations, New York and Geneva (Sales No: E/F.98.II.D.16).

UNCTAD-WTO (1998), "Market Access Developments since the Uruguay Round: Implications, Opportunities and Challenges, in Particular for Developing Countries and Least-Developed Countries, in the Context of Globalization and Liberalization", Report by the UNCTAD Secretariat and the WTO Secretariat, Geneva.

WTO (1999), Guide to the Uruguay Round Agreement, Kluwer Law International, The Hague and WTO, Geneva. 
TABLES

TABLE 1. POST-URUGUAY ROUND IMPORT WEIGHTED APPLIED AND BOUND TARIFF RATES

(Percentages)

\begin{tabular}{lcc}
\hline Country group or region & Applied & Bound \\
\hline World & 4.3 & 6.5 \\
High income economies & 2.5 & 3.5 \\
Latin America & 11.7 & 32.7 \\
East Asia \& Pacific & 11.9 & 21.0 \\
South Asia & 30.4 & 50.8 \\
Eastern Europe & 6.7 & 13.3 \\
Rest of Europe & 24.2 & 16.3 \\
North Africa & 24.8 & 48.7 \\
Sub-Saharan Africa & 9.0 & 19.4 \\
\hline
\end{tabular}

Source: Finger, Ingco and Reincke (1996)

Note: Weighted averages, excluding trade within FTAs. The applied rates are those for the base period, while the bound rates are those applying after the implementation. The data on developing countries was based on 26 out of 93 developing country participants in the Round, representing 80 per cent of merchandise trade and 30 per cent of tariff lines. 
TABLE 2: POST-URUGUAY ROUND APPLIED AND BOUND RATES OF DEVELOPED AND DEVELOPING COUNTRIES BY MAJOR PRODUCT GROUP

(Per cent)

\begin{tabular}{lcccc}
\hline Product Group & \multicolumn{2}{c}{ Developed } & \multicolumn{2}{c}{ Developing } \\
\cline { 2 - 5 } & Applied & Bound & Applied & Bound \\
\hline Agriculture exc. Fish & 5.2 & 7.2 & 18.6 & 19.9 \\
Fish \& fish products & 4.2 & 4.9 & 8.6 & 25.9 \\
Petroleum & 0.7 & 0.9 & 7.9 & 8.4 \\
Wood, pulp, paper \& furniture & 0.5 & 0.9 & 8.9 & 10.3 \\
Textiles \& clothing & 8.4 & 11.0 & 21.2 & 25.5 \\
Leather, rubber, footwear & 5.5 & 6.5 & 14.9 & 15.4 \\
Metals & 0.9 & 1.6 & 10.8 & 10.4 \\
Chemical \& photo. Supplies & 2.2 & 3.6 & 12.4 & 16.8 \\
Transport equipment & 4.2 & 5.6 & 19.9 & 13.2 \\
Non-electric machinery & 1.1 & 1.9 & 13.5 & 14.5 \\
Electric machinery & 2.3 & 3.7 & 14.6 & 17.2 \\
Mineral prods., precious stones \& & 0.7 & 1.0 & 7.8 & 8.1 \\
metals & & & & \\
Manufactures, n.e.s. & 1.4 & 2.0 & 12.1 & 9.2 \\
Industrial Goods (Rows 4-13) & 2.5 & 3.5 & 13.3 & 13.3 \\
All merchandise trade & $\mathbf{2 . 6}$ & $\mathbf{3 . 7}$ & $\mathbf{1 3 . 3}$ & $\mathbf{1 3 . 0}$ \\
\hline
\end{tabular}

Source: Finger, Ingco and Reincke (1996)

Notes: Weighted averages, excluding trade within FTAs. The applied rates are those for the base period, while the bound rates are those applying after the implementation; in some instances this means that the applied rates are higher than the bound rates. 
TABLE 3: TARIFF ESCALATION ON PRODUCTS IMPORTED BY DEVELOPED ECONOMIES FROM DEVELOPING ECONOMIES

(Millions of US dollars and percentages)

\begin{tabular}{lc}
\hline Product & Post-UR bound tariff \\
\hline All industrial products (exc. Petroleum) & 4.3 \\
- Raw materials & 0.8 \\
- Semi-manufactures & 2.8 \\
- Finished products & 6.2 \\
All tropical products & 1.9 \\
- Raw materials & 0.0 \\
- Semi-manufactures & 3.5 \\
- Finished products & 2.6 \\
Natural resource-based products & 2.7 \\
- Raw materials & 2.0 \\
- Semi-manufactures & 2.0 \\
- Finished products & 5.9 \\
\hline
\end{tabular}

Source: GATT (1994). 
TABLE 4: IMPORT COVERAGE OF MAJOR NTBS IN OECD COUNTRIES

(A) 1989

\begin{tabular}{|c|c|c|c|c|c|c|c|c|c|c|}
\hline Indicator & Australia & $\mathbf{E U}$ & Iceland & Japan & New Zealand & Norway & Mexico & Turkey & Switzerland & USA \\
\hline All NTBs & 3.4 & 26.6 & n.a. & 13.1 & 14.1 & 26.6 & 2.0 & 0.1 & 12.9 & 25.5 \\
\hline - Core NTBs & 3.4 & 25.2 & n.a. & 12.5 & 14.1 & 25.2 & 2.0 & 0.0 & 3.3 & 25.5 \\
\hline Quantitative restrictions (QRs) & 0.5 & 19.5 & & 11.7 & 13.9 & 19.5 & 1.9 & 0.0 & 1.7 & 20.4 \\
\hline - Export restraints & 0.0 & 15.5 & n.a. & 0.3 & 0.0 & 15.5 & 0.0 & 0.0 & 0.0 & 19.5 \\
\hline - Non-auto licensing & 0.5 & 4.4 & n.a. & 8.9 & 0.0 & 4.3 & 1.8 & 0.0 & 0.4 & 0.0 \\
\hline - Other QRs & 0.0 & 0.2 & & 2.8 & 13.9 & 0.2 & 0.2 & 0.0 & 1.4 & 6.6 \\
\hline Price controls (PCMs) & 2.9 & 12.4 & n.a. & 0.8 & 0.3 & 12.4 & 0.1 & 0.0 & 1.6 & 17.8 \\
\hline - Variable levies & 0.0 & 6.3 & n.a. & 0.8 & 0.0 & 6.3 & 0.0 & 0.0 & 1.5 & 0.1 \\
\hline - AD/CVs \& VEPRs & 2.9 & 2.6 & n.a. & 0.0 & 0.3 & 2.6 & 0.1 & 0.0 & 0.0 & 17.8 \\
\hline - Other PCMs & 0.0 & 4.3 & $\begin{array}{l}\text { n.a. } \\
\text { n.a. }\end{array}$ & 0.0 & 0.0 & 4.3 & 0.0 & 0.0 & 0.1 & 0.0 \\
\hline
\end{tabular}




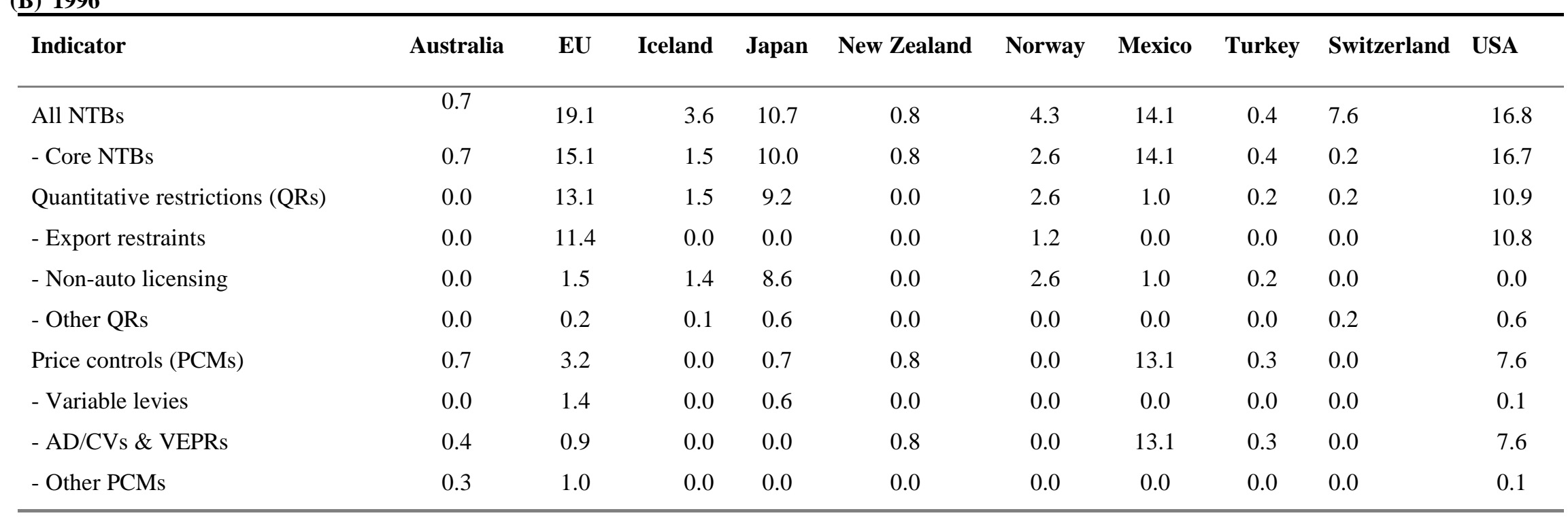

Source: OECD (1997).

Notes: "Core" NTBs are QRs and PCMs shown in the table, imposed "with the specific intent of modifying or restricting international trade" (OECD, 1997).

Non-core NTBs include automatic licensing and monitoring measures. See OECD (1997) for further details of methodology. 
TABLE 5: IMPORT COVERAGE OF CORE NTBS IN OECD COUNTRIES BY MAJOR SECTOR

(A) 1989

\begin{tabular}{|c|c|c|c|c|c|c|c|c|c|c|c|}
\hline ISIC & Description & Australia & $\mathbf{E U}$ & Iceland & Japan & $\begin{array}{c}\text { New } \\
\text { Zealand }\end{array}$ & Norway & Mexico & Turkey & Switzerland & USA \\
\hline 1 & Agric., forestry \& fishing & 0.9 & 18.8 & n.a. & 11.3 & 0.6 & 14.2 & 6.7 & 0.0 & 12.7 & 5.5 \\
\hline 21 & - Coal mining & n.a. & 0.0 & n.a. & n.a. & n.a. & 0.0 & 0.0 & n.a. & 0.0 & 0.0 \\
\hline 22 & - Crude petroleum & n.a. & n.a. & n.a. & n.a. & n.a. & 0.0 & 66.7 & n.a. & n.a. & 0.0 \\
\hline 23 & - Metal ores & n.a. & n.a. & n.a. & n.a. & n.a. & 0.0 & 0.0 & n.a. & n.a. & 0.0 \\
\hline 29 & - Other & n.a. & 0.0 & n.a. & n.a. & n.a. & 0.0 & 0.0 & n.a. & 0.0 & 3.4 \\
\hline 31 & - Food, bevs., tobacco & 2.1 & 48.5 & n.a. & 24.3 & 0.0 & 13.3 & 15.0 & 0.0 & 25.2 & 16.4 \\
\hline 32 & - Textiles \& apparel & 0.5 & 74.9 & n.a. & 28.8 & 0.0 & 34.1 & 0.5 & 0.0 & 0.0 & 84.1 \\
\hline 33 & - Wood \& wood prods & 0.0 & 0.0 & n.a. & 0.0 & 0.0 & 3.7 & 0.0 & 0.0 & 0.0 & 3.9 \\
\hline 34 & - Paper \& paper prods & 0.2 & 1.2 & n.a. & 0.0 & 0.5 & 0.0 & 3.8 & 0.0 & 0.0 & 1.5 \\
\hline 35 & $\begin{array}{l}\text { - Chemical \& petroleum } \\
\text { prods }\end{array}$ & 2.2 & 3.5 & n.a. & 1.4 & 20.4 & 3.8 & 1.7 & 0.0 & 0.0 & 8.6 \\
\hline 36 & $\begin{array}{l}\text { - Non-metallic mineral } \\
\text { prods }\end{array}$ & 4.3 & 4.4 & n.a. & 0.0 & 0.0 & 0.0 & 1.9 & 0.0 & 0.0 & 10.7 \\
\hline \multirow[t]{2}{*}{39} & - Other & 5.5 & 1.3 & n.a. & 0.0 & 0.0 & 0.2 & 0.0 & 0.0 & 0.0 & 4.2 \\
\hline & Total & 3.4 & 12.7 & n.a. & 4.4 & 2.7 & 3.4 & 8.4 & 0.0 & 3.3 & 17.2 \\
\hline
\end{tabular}

Source: OECD (1997).

Notes: See OECD (1997) for details of methodology. Sectoral production coverage refers to the value added covered by NTBs. 
TABLE 6: IMPORT COVERAGE OF CORE NTBS IN OECD COUNTRIES BY MAJOR SECTOR (CONTINUED)

\begin{tabular}{|c|c|c|c|c|c|c|c|c|c|c|c|}
\hline ISIC & Description & Australia & $\mathbf{E U}$ & Iceland & Japan & $\begin{array}{c}\text { New } \\
\text { Zealand }\end{array}$ & Norway & Mexico & Turkey & Switzerland & USA \\
\hline 2 & Mining \& quarrying & 0.0 & 6.7 & n.a. & 0.4 & 0.0 & 0.0 & 24.5 & 0.0 & 0.0 & 0.4 \\
\hline 21 & - Coal mining & n.a. & 42.9 & n.a. & n.a. & n.a. & 0.0 & 0.0 & n.a. & 0.0 & 0.0 \\
\hline 22 & - Crude petroleum & n.a. & 0.0 & n.a. & n.a. & n.a. & 0.0 & 46.2 & n.a. & n.a. & 0.0 \\
\hline 23 & - Metal ores & n.a. & 4.4 & n.a. & n.a. & n.a. & 0.0 & 0.0 & n.a. & n.a. & 4.0 \\
\hline 3 & Manufacturing & 1.7 & 5.4 & 0.1 & 2.5 & 0.0 & 0.9 & 12.9 & 0.3 & 0.1 & 8.1 \\
\hline 31 & - Food, bevs., tobacco & 8.3 & 11.1 & 0.0 & 8.6 & 0.0 & 0.0 & 1.9 & 0.0 & 0.8 & 1.2 \\
\hline 32 & - Textiles \& apparel & 0.0 & 75.4 & 0.0 & 28.7 & 0.0 & 24.3 & 70.6 & 0.0 & 0.0 & 68.3 \\
\hline 33 & - Wood \& wood prods & 0.0 & 0.0 & 0.0 & 0.0 & 0.0 & 0.0 & 0.0 & 0.0 & 0.0 & 0.8 \\
\hline 34 & - Paper \& paper prods & 0.0 & 1.9 & 0.0 & 0.0 & 0.0 & 0.0 & 0.0 & 0.1 & 0.0 & 1.3 \\
\hline 35 & $\begin{array}{l}\text { - Chemical \& petroleum } \\
\text { prods }\end{array}$ & 0.6 & 1.6 & 0.0 & 1.4 & 0.2 & 3.7 & 3.8 & 0.0 & 0.0 & 3.2 \\
\hline 36 & $\begin{array}{l}\text { - Non-metallic mineral } \\
\text { prods }\end{array}$ & 0.5 & 0.0 & 0.0 & 0.0 & 0.0 & 0.0 & 0.4 & 6.6 & 0.0 & 6.1 \\
\hline 38 & - Fabricated metals & 0.2 & 0.0 & 0.0 & 0.0 & 0.0 & 0.0 & 15.1 & 0.0 & 0.0 & 6.1 \\
\hline \multirow[t]{2}{*}{39} & - Other & 0.0 & 0.0 & 1.3 & 0.0 & 0.0 & 0.2 & 31.9 & 0.0 & 0.0 & 1.7 \\
\hline & Total & 1.5 & 5.6 & 0.1 & 2.8 & 0.0 & 0.4 & 11.8 & 0.2 & 0.1 & 7.2 \\
\hline
\end{tabular}

Source: OECD (1997).

Notes: See OECD (1997) for details of methodology. Sectoral production coverage refers to the value added covered by NTBs. 
TABLE 7: OECD PRODUCER SUBSIDY EQUIVALENTS BY COUNTRY, 1986-97 (per cent)

\begin{tabular}{lccccc}
\hline Country or group & $\mathbf{1 9 8 6 - 8 8}$ & $\mathbf{1 9 9 2 - 9 4}$ & $\mathbf{1 9 9 5}$ & $\mathbf{1 9 9 6 p}$ & $\mathbf{1 9 9 7 e}$ \\
\hline Australia & 10 & 10 & 10 & 8 & 0 \\
Canada & 42 & 31 & 22 & 22 & 20 \\
European Union $^{1}$ & 48 & 48 & 49 & 43 & 42 \\
Iceland $_{\text {Japan }}$ & 82 & 77 & 75 & 69 & 68 \\
New Zealand & 73 & 74 & 76 & 71 & 69 \\
Norway & 18 & 3 & 3 & 3 & 3 \\
Switzerland & 74 & 74 & 72 & 70 & 71 \\
Turkey & 79 & 80 & 79 & 77 & 76 \\
United States & 26 & 32 & 30 & 25 & 38 \\
OECD & 2,3 & 21 & 13 & 15 & 16 \\
Czech Republic & 40 & 42 & 40 & 35 & 35 \\
Hungary & 45 & 26 & 15 & 14 & 11 \\
Mexico & 54 & 25 & 21 & 15 & 16 \\
Poland & 24 & 34 & 0 & 8 & 16 \\
OECD $^{2,4}$ & 23 & 19 & 19 & 23 & 22 \\
\hline
\end{tabular}

Notes: e-estimate; $\mathrm{p}$ - provisional

1. EU12 for 1986-94, EU15 from 1995. EU includes GDR from 1990.

2. Austria, Finland and Sweden are included in the OECD total for the 1986-94 period, and in the EU for 1995-97.

3. Excludes Korea, the Czech Republic, Hungary, Mexico and Poland.

4. Excludes Korea.

Source: OECD (1998). 
TABLE 8: FREQUENCY OF MAJOR NTBS IN SELECTED DEVELOPING COUNTRIES, 1995-1998

(Per cent)

\begin{tabular}{lcccccc}
\hline Country & $\begin{array}{l}\text { Non-auto } \\
\text { licensing }\end{array}$ & Prohibitions & Quotas & Tarif Quotas & $\begin{array}{c}\text { Import } \\
\text { Monitoring }\end{array}$ & Var. levies \\
\hline Argentina & 1 & 0 & 1 & 0 & 0 & 1 \\
Brazil & 11 & 11 & 1 & 0 & 0 & 1 \\
Chile & 0 & 1 & 0 & 0 & 0 & 4 \\
Colombia & 6 & 1 & 0 & 0 & 0 & 6 \\
Costa Rica & 6 & 0 & 0 & 6 & 0 & 0 \\
Côte d'Ivoire & 31 & 0 & 5 & 0 & 0 & 0 \\
Dominican R. & 5 & 1 & 0 & 0 & 1 & 0 \\
El Salvador & 5 & 1 & 1 & 0 & 0 & 0 \\
Fiji & 5 & 0 & 0 & 0 & 0 & 0 \\
Hong Kong & 2 & 0 & 0 & 0 & 0 & 0 \\
India & 94 & 1 & 0 & 0 & 0 & 0 \\
Indonesia & 31 & 0 & 0 & 7 & 0 & 0 \\
Malaysia & 20 & 14 & 2 & 0 & 0 & 0 \\
Mauritius & 9 & 7 & 0 & 7 & 0 & 0 \\
Mexico & 6 & 1 & 0 & 1 & 0 & 0 \\
Morocco & 13 & 0 & 0 & 0 & 0 & 0 \\
Nigeria & 2 & 9 & 0 & 0 & 0 & 0 \\
Singapore & 1 & 1 & 0 & 0 & 0 & 0 \\
South Africa & 5 & 0 & 3 & 0 & 0 & 0 \\
Sri Lanka & 23 & 0 & 0 & 12 & 0 & 0 \\
Thailand & 11 & 6 & 1 & 0 & 0 & 0 \\
Uganda & 3 & 0 & 0 & 0 & 0 & 0 \\
Venezuela & 2 & 3 & 1 & & 0 & 0 \\
Average & 10 & 2 & 0 & 0 & 0 \\
\hline & & 0 & 0 & 0 & 0 \\
\end{tabular}

Source: Michalopoulos (1999), based on WTO Trade Policy Reviews of the individual countries.

Notes: Frequencies in per cent of total HS 2-digit categories. See Michalopoulos (1999) for further details of methodology. 
TABLE 9: FREQUENCY OF NTBS IN MAJOR SECTOR BY DEVELOPING COUNTRIES, 1995-98

(Per cent)

\begin{tabular}{|l|l|l|c|c|c|c|}
\hline HS & Description & $\begin{array}{l}\text { Non-auto } \\
\text { licensing }\end{array}$ & Prohibitions & Quotas & $\begin{array}{l}\text { Tariff } \\
\text { Quotas }\end{array}$ & $\begin{array}{l}\text { Var. levies \& } \\
\text { Admin. } \\
\text { Pricing }\end{array}$ \\
\hline I & Animal products & 14 & 3 & 0 & 9 & 3 \\
\hline II & Vegetables & 19 & 3 & 2 & 9 & 3 \\
\hline III & Fats \& oils & 17 & 7 & 0 & 10 & 13 \\
\hline IV & Prepared foodstuffs & 11 & 2 & 1 & 4 & 3 \\
\hline V & Minerals & 24 & 6 & 0 & 2 & 0 \\
\hline VI & Chemicals & 9 & 1 & 0 & 2 & 0 \\
\hline VII & Plastics & 17 & 7 & 2 & 2 & 2 \\
\hline VIII & Leather & 2 & 0 & 0 & 0 & 0 \\
\hline IX & Wood & 6 & 2 & 0 & 2 & 0 \\
\hline X & Pulp and paper & 4 & 1 & 0 & 2 & 0 \\
\hline XI & Textiles & 7 & 1 & 2 & 2 & 0 \\
\hline XII & Footwear & 3 & 0 & 0 & 1 & 0 \\
\hline XIII & Glass & 6 & 1 & 0 & 1 & 0 \\
\hline XIV & Pearls & 17 & 0 & 0 & 0 & 0 \\
\hline XV & Base metals & 7 & 2 & 0 & 2 & 0 \\
\hline XVI & Mach. \& elec. equip. & 22 & 7 & 0 & 3 & 0 \\
\hline XVII & Vehicles & 11 & 6 & 2 & 1 & 0 \\
\hline XVIII & Instruments & 4 & 0 & 0 & 0 & 0 \\
\hline XIX & Arms & 3 & 0 & 0 & 3 & 0 \\
\hline XX & Other manufs. & 7 & 1 & 0 & 0 & 0 \\
\hline XXI & Works of art, & 3 & 0 & 0 & 0 & 0 \\
\hline & & & & & \\
\hline
\end{tabular}

Source: Michalopoulos (1999), based on WTO Trade Policy Reviews of the individual countries.

Notes: Percentages of countries using the measures in each HS 2-digit category. See Michalopoulos (1999) for further details of methodology. 
Table 10: Anti-dumping investigations by groups of reporting countries and countries investigated, 1987-97

\begin{tabular}{lcccc}
\hline $\begin{array}{l}\text { Reporting } \\
\text { country group }\end{array}$ & Developed & Developing & $\begin{array}{c}\text { Economies in } \\
\text { Transition }\end{array}$ & Total \\
\hline & 570 & 591 & 340 & \\
\hline Developed & 249 & 216 & 205 & 1,501 \\
Developing & 24 & 0 & 1 & 670 \\
Economies in & 843 & 807 & 546 & 25 \\
Transition & & & & 2,196 \\
Total & & & & \\
\hline
\end{tabular}

Source: Miranda, Torres and Ruiz (1998). 
TABLE 11: SECTORAL COVERAGE OF SPECIFIC COMMITMENTS IN SERVICES (Per cent)

\begin{tabular}{|c|c|c|c|}
\hline & $\begin{array}{l}\text { H igh Income } \\
\text { Countries }\end{array}$ & $\begin{array}{l}\text { Low \& Middle } \\
\text { Income Countries }\end{array}$ & $\begin{array}{l}\text { Large } \\
\text { Developing } \\
\text { Countries }\end{array}$ \\
\hline \multicolumn{4}{|l|}{ Market Access } \\
\hline $\begin{array}{l}\text { Unweighted average count (sectors-modes } \\
\text { as a share of maximum possible }\end{array}$ & 47.3 & 16.2 & 38.6 \\
\hline $\begin{array}{l}\text { Average coverage (sectors-modes listed as } \\
\text { a share of maximum possible, weighted } \\
\text { by openness/binding factors) }\end{array}$ & 35.9 & 10.3 & 22.9 \\
\hline $\begin{array}{l}\text { Coverage/count (average coverage as a } \\
\text { share of the average count }\end{array}$ & 75.9 & 63.6 & 59.3 \\
\hline $\begin{array}{l}\text { "No restrictions" as a share of total offer } \\
\text { (unweighted count) }\end{array}$ & 57.3 & 45.5 & 38.7 \\
\hline $\begin{array}{l}\text { "No restrictions" as a share of maximum } \\
\text { possible }\end{array}$ & 27.1 & 7.3 & 14.9 \\
\hline \multicolumn{4}{|l|}{ National treatment } \\
\hline $\begin{array}{l}\text { Unweighted average count (sectors-modes } \\
\text { as a share of maximum possible }\end{array}$ & 47.3 & 16.2 & 38.8 \\
\hline $\begin{array}{l}\text { Average coverage (sectors-modes listed as } \\
\text { a share of maximum possible, weighted } \\
\text { by openness/binding factors) }\end{array}$ & 37.2 & 11.2 & 25.5 \\
\hline $\begin{array}{l}\text { Coverage/count (average coverage as a } \\
\text { share of the average count }\end{array}$ & 78.6 & 69.1 & 66.1 \\
\hline $\begin{array}{l}\text { "No restrictions" as a share of total offer } \\
\text { (unweighted count) }\end{array}$ & 65.1 & 58.0 & 52.3 \\
\hline $\begin{array}{l}\text { "No restrictions" as a share of maximum } \\
\text { possible }\end{array}$ & 30.8 & 9.4 & 20.2 \\
\hline \multicolumn{4}{|l|}{ Memo items: } \\
\hline $\begin{array}{l}\text { No restrictions on MA and NT as a share } \\
\text { of maximum possible }\end{array}$ & 24.8 & 6.9 & 14.3 \\
\hline
\end{tabular}

Source: Hoekman (1996) 
TABLE 12: COMMITMENTS BY SERVICES SECTOR

\begin{tabular}{lccccc}
\hline & $\begin{array}{c}\text { No. of GATS } \\
\text { sectors }\end{array}$ & \multicolumn{2}{c}{ Av. no. of commitments } & \multicolumn{2}{c}{$\begin{array}{c}\text { Commitments/GATS items per } \\
\text { sector }\end{array}$} \\
\cline { 3 - 6 } & & High income & $\begin{array}{c}\text { Low \& } \\
\text { middle } \\
\text { income } \\
\text { countries }\end{array}$ & $\begin{array}{c}\text { High income } \\
\text { countries }\end{array}$ & $\begin{array}{c}\text { Low \& middle } \\
\text { income } \\
\text { countries }\end{array}$ \\
\hline Construction & & & & \\
Motor vehicle repair & 20 & 11.2 & 3.3 & 56.0 & 16.5 \\
Wholesale trade & 4 & 1.8 & 0.3 & 45.0 & 7.5 \\
Retail trade & 8 & 4.6 & 0.5 & 57.5 & 6.3 \\
Hotels, restaurants & 8 & 4.4 & 0.8 & 55.0 & 10.0 \\
Land transport & 4 & 2.8 & 2.8 & 70.0 & 70.0 \\
Water transport & 40 & 9.4 & 2.3 & 23.5 & 5.8 \\
Air transport & 48 & 4.4 & 3.0 & 9.2 & 6.3 \\
Auxiliary transport & 20 & 3.7 & 1.5 & 18.5 & 7.5 \\
Postal services & 20 & 5.1 & 1.3 & 25.5 & 6.5 \\
Basic telecommunications & 4 & 1.3 & 0.6 & 32.5 & 15.0 \\
Value added telecomms & 28 & 1.5 & 1.3 & 5.4 & 4.6 \\
Financial services & 28 & 18.7 & 5.0 & 66.8 & 7.8 \\
Real estate services & 60 & 31.3 & 12.4 & 52.2 & 20.6 \\
Rental activities & 8 & 3.5 & 0.3 & 43.8 & 3.8 \\
Computer-related & 20 & 9.5 & 1.3 & 47.5 & 6.5 \\
R\&D services & 20 & 15.5 & 4.2 & 77.5 & 21.0 \\
Business services & 12 & 4.1 & 1.0 & 34.2 & 0.3 \\
Refuse disposal & 108 & 56.5 & 12.2 & 47.9 & 6.3 \\
Education & 16 & 8.8 & 1.0 & 55.0 & 6.5 \\
Health \& social & 20 & 4.7 & 1.3 & 23.5 & 7.9 \\
Recreation \& culture & 24 & 5.0 & 1.9 & 20.8 & 9.6 \\
\hline
\end{tabular}

Source: Hoekman (1995) 
Chart 1: Comparison of $50 \%$ LinearCut with Swiss (14) formula

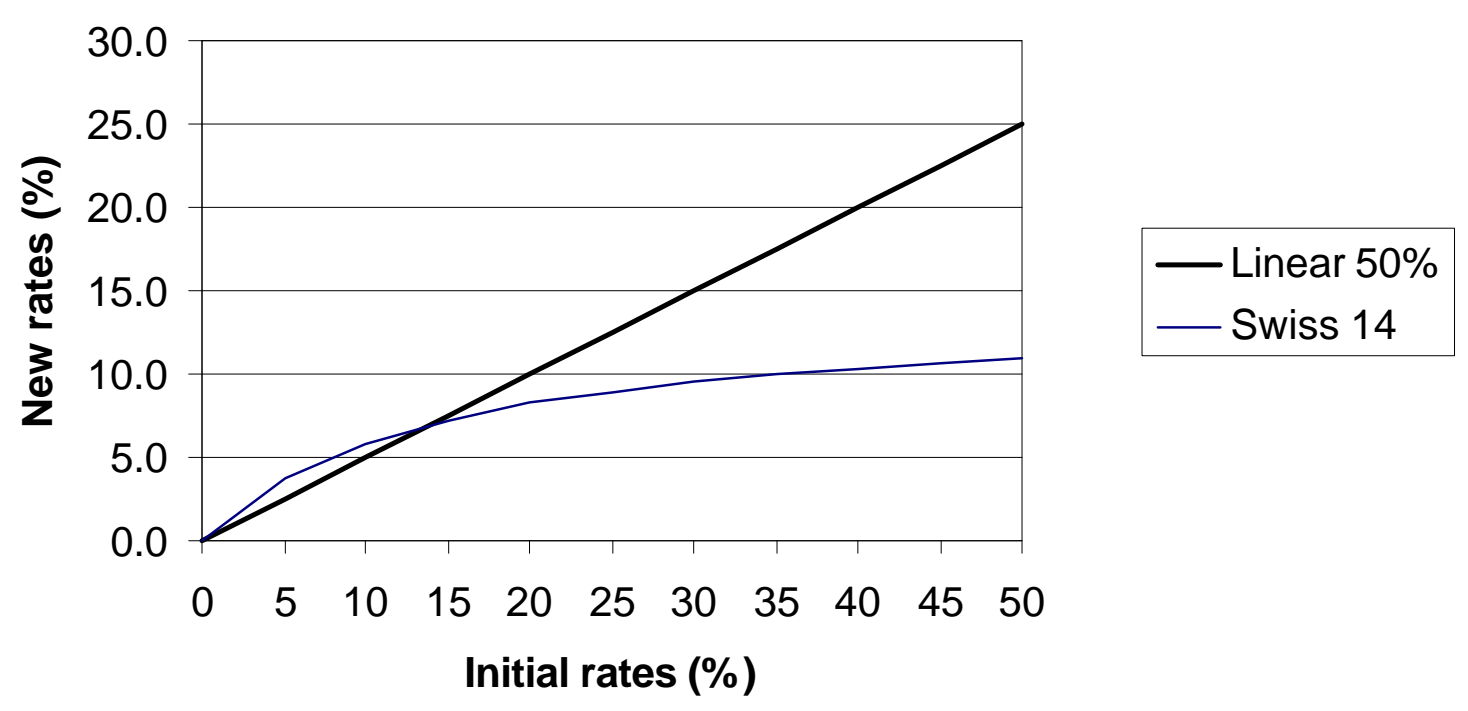





\section{CREDIT PAPERS}

98/1 Norman Gemmell and Mark McGillivray, "Aid and Tax Instability and the Government Budget Constraint in Developing Countries"

98/2 Susana Franco-Rodriguez, Mark McGillivray and Oliver Morrissey, “Aid and the Public Sector in Pakistan: Evidence with Endogenous Aid"

98/3 Norman Gemmell, Tim Lloyd and Marina Mathew, "Dynamic Sectoral Linkages and Structural Change in a Developing Economy"

98/4 Andrew McKay, Oliver Morrissey and Charlotte Vaillant, "Aggregate Export and Food Crop Supply Response in Tanzania"

98/5 Louise Grenier, Andrew McKay and Oliver Morrissey, "Determinants of Exports and Investment of Manufacturing Firms in Tanzania"

98/6 P.J. Lloyd, "A Generalisation of the Stolper-Samuelson Theorem with Diversified Households: A Tale of Two Matrices"

98/7 P.J. Lloyd, "Globalisation, International Factor Movements and Market

98/8 Ramesh Durbarry, Norman Gemmell and David Greenaway, "New Evidence on the Impact of Foreign Aid on Economic Growth"

98/9 Michael Bleaney and David Greenaway, "External Disturbances and Macroeconomic Performance in Sub-Saharan Africa"

98/10 Tim Lloyd, Mark McGillivray, Oliver Morrissey and Robert Osei, "Investigating the Relationship Between Aid and Trade Flows"

98/11 A.K.M. Azhar, R.J.R. Eliott and C.R. Milner, "Analysing Changes in Trade Patterns: A New Geometric Approach"

98/12 Oliver Morrissey and Nicodemus Rudaheranwa, "Ugandan Trade Policy and Export Performance in the 1990s"

98/13 Chris Milner, Oliver Morrissey and Nicodemus Rudaheranwa, "Protection, Trade Policy and Transport Costs: Effective Taxation of Ugandan Exporters"

99/1 Ewen Cummins, "Hey and Orme go to Gara Godo: Household Risk Preferences"

99/2 Louise Grenier, Andrew McKay and Oliver Morrissey, "Competition and Business Confidence in Manufacturing Enterprises in Tanzania"

99/3 Robert Lensink and Oliver Morrissey, "Uncertainty of Aid Inflows and the Aid-Growth Relationship"

99/4 Michael Bleaney and David Fielding, "Exchange Rate Regimes, Inflation and Output Volatility in Developing Countries"

99/5 Indraneel Dasgupta, “Women's Employment, Intra-Household Bargaining and Distribution: A Two-Sector Analysis"

99/6 Robert Lensink and Howard White, "Is there an Aid Laffer Curve?"

99/7 David Fielding, "Income Inequality and Economic Development: A Structural

99/8 Christophe Muller, "The Spatial Association of Price Indices and Living

99/9 Christophe Muller, "The Measurement of Poverty with Geographical and Intertemporal Price Dispersion" 
99/10 Henrik Hansen and Finn Tarp, "Aid Effectiveness Disputed"

99/11 Christophe Muller, "Censored Quantile Regressions of Poverty in Rwands"

99/12 Michael Bleaney, Paul Mizen and Lesedi Senatla, "Portfolio Capital Flows to Emerging Markets"

99/13 Christophe Muller, "The Relative Prevalence of Diseases in a Population if Ill

00/1 Robert Lensink, "Does Financial Development Mitigate Negative Effects of Policy Uncertainty on Economic Growth?"

00/2 Oliver Morrissey, "Investment and Competition Policy in Developing Countries: Implications of and for the WTO"

00/3 Jo-Ann Crawford and Sam Laird, "Regional Trade Agreements and the

00/4 Sam Laird, "Multilateral Market Access Negotiations in Goods and Services" 


\section{DEPARTMENT OF ECONOMICS DISCUSSION PAPERS}

In addition to the CREDIT series of research papers the Department of Economics produces a discussion paper series dealing with more general aspects of economics. Below is a list of recent titles published in this series.

97/1 David Fielding, "The Social and Economic Determinants of Voter Behaviour: Evidence from the 1992 General Election in Scotland".

97/2 David Fielding and Paul Mizen, "Currency and Banking Crises with Endogenous Government Behavior".

97/3 Rod Falvey, "Trade Policy and Growth Theory: Recent Advances".

97/4 Mark A. Roberts, Karsten Staehr and Torben Tranaes, "Two-Stage Bargaining and Minimum Wages in a Dual Labour Market".

97/5 Paul Mizen, "The Declaration of Independence: Can a Central Bank Credibly Commit Itself to Low Inflation?"

97/6 Stephen J. Leybourne and Paul Mizen, "Disinflation and Central Bank Independence in Australia, Canada and New Zealand: Evidence from Smooth Transition Analysis".

97/7 P. Newbold, A.J. Rayner, N. Kellard and C. Ennew, "Long-Run Price Behaviour of Wheat and Maize: Trend Stationarity or DifferenceStationarity?"

97/8 P. Newbold, A.J. Rayner, N. Kellard and C. Ennew, "Is the Dollar/ECU Exchange A Random Walk?"

97/9 T.A. Lloyd and A.J. Rayner, "A Cointegration Analysis of Price Relationships on the World Wheat Market"

97/10 Steven J. Humphrey, "A Note on Alternative Explanations of Cyclical Choices"

97/11 Walter Bossert, "Welfarism and Information Invariance"

97/12 Charles Blackorby, Walter Bossert and David Donaldson, "Rationalizable Solutions to Pure Population Problems"

97/13 Mark A. Roberts, "Central and Two-Stage Wage Setting and Minimum Wages in a Model With Imperfect Competition and Multiple Technological Equilibria"

97/14 Mark A. Roberts, "The Implausability of Cycles in the Diamond Overlapping Generations Model"

97/15 Michael Bleaney, "The Dynamics of Money and Prices Under Alternative Exchange Rate Regimes: An Empirical Investigation"

97/16 Emmanuel Petrakis and Joanna Poyago-Theotoky, "Environmental Impact of Technology Policy: R\&D Subsidies Versus R\&D Cooperation"

97/17 Charles Blackorby, Walter Bossert and David Donaldson, "PriceIndependent Welfare Prescriptions and Population Size"

97/18 Prasanta K. Pattanaik and Yongsheng Xu, "On Diversity and Freedom of Choice"

97/19 Wulf Gaertner and Yongsheng Xu, "On the Structure of Choice Under Different External References"

98/1 David Fielding, "Social and Economic Determinants of English Voter Choice in the 1997 General Election" 
98/2 Darrin L. Baines, Nicola Cooper and David K. Whynes, "General Practitioners' Views on Current Changes in the UK Health Service"

98/3 Prasanta K. Pattanaik and Yongsheng Xu, "On Ranking Opportunity Sets in Economic Environments"

98/4 David Fielding and Paul Mizen, "Panel Data Evidence on the Relationship Between Relative Price Variability and Inflation in Europe"

98/5 John Creedy and Norman Gemmell, "The Built-In Flexibility of Taxation: Some Basic Analytics"

98/6 Walter Bossert, "Opportunity Sets and the Measurement of Information"

98/7 Walter Bossert and Hans Peters, "Multi-Attribute Decision-Making in Individual and Social Choice"

98/8 Walter Bossert and Hans Peters, "Minimax Regret and Efficient Bargaining under Uncertainty"

98/9 Michael F. Bleaney and Stephen J. Leybourne, "Real Exchange Rate Dynamics under the Current Float: A Re-Examination"

98/10 Norman Gemmell, Oliver Morrissey and Abuzer Pinar, "Taxation, Fiscal Illusion and the Demand for Government Expenditures in the UK: A TimeSeries Analysis"

98/11 Matt Ayres, "Extensive Games of Imperfect Recall and Mind Perfection"

98/12 Walter Bossert, Prasanta K. Pattanaik and Yongsheng Xu, "Choice Under Complete Uncertainty: Axiomatic Characterizations of Some Decision Rules"

98/13 T. A. Lloyd, C. W. Morgan and A. J. Rayner, "Policy Intervention and Supply Response: the Potato Marketing Board in Retrospect"

98/14 Richard Kneller, Michael Bleaney and Norman Gemmell, "Growth, Public Policy and the Government Budget Constraint: Evidence from OECD Countries"

98/15 Charles Blackorby, Walter Bossert and David Donaldson, "The Value of Limited Altruism"

98/16 Steven J. Humphrey, “The Common Consequence Effect: Testing a Unified Explanation of Recent Mixed Evidence"

98/17 Steven J. Humphrey, "Non-Transitive Choice: Event-Splitting Effects or

98/18 Richard Disney and Amanda Gosling, "Does It Pay to Work in the Public

98/19 Norman Gemmell, Oliver Morrissey and Abuzer Pinar, "Fiscal Illusion and the Demand for Local Government Expenditures in England and Wales"

98/20 Richard Disney, "Crises in Public Pension Programmes in OECD: What Are the Reform Options?"

98/21 Gwendolyn C. Morrison, "The Endowment Effect and Expected Utility"

98/22 G.C. Morrisson, A. Neilson and M. Malek, "Improving the Sensitivity of the Time Trade-Off Method: Results of an Experiment Using Chained TTO Questions"

99/1 Indraneel Dasgupta, "Stochastic Production and the Law of Supply"

99/2 Walter Bossert, "Intersection Quasi-Orderings: An Alternative Proof"

99/3 Charles Blackorby, Walter Bossert and David Donaldson, "Rationalizable Variable-Population Choice Functions" 
99/17 Indraneel Dasgupta, Subodh Kumar and Prasanta K. Pattanaik, "Consistent Choice and Falsifiability of the Maximization Hypothesis"

99/18 David Fielding and Paul Mizen, "Relative Price Variability and Inflation in

99/19 Emmanuel Petrakis and Joanna Poyago-Theotoky, "Technology Policy in an Oligopoly with Spillovers and Pollution"

99/20 Indraneel Dasgupta, "Wage Subsidy, Cash Transfer and Individual Welfare in a Cournot Model of the Household"

99/21 Walter Bossert and Hans Peters, "Efficient Solutions to Bargaining Problems with Uncertain Disagreement Points"

99/22 Yongsheng Xu, "Measuring the Standard of Living - An Axiomatic

99/23 Yongsheng Xu, "No-Envy and Equality of Economic Opportunity"

99/24 M. Conyon, S. Girma, S. Thompson and P. Wright, "The Impact of Mergers and Acquisitions on Profits and Employee Remuneration in the United Kingdom"

99/25 Robert Breunig and Indraneel Dasgupta, "Towards an Explanation of the Cash-Out Puzzle in the US Food Stamps Program"

99/26 John Creedy and Norman Gemmell, "The Built-In Flexibility of Consumption Taxes" 
99/37 Tae-Hwan Kim, Stephen J. Leybourne and Paul Newbold, "Spurious Rejections by Perron Tests in the Presence of a Misplaced or Second Break Under the Null"

00/1 Tae-Hwan Kim and Christophe Muller, “Two-Stage Quantile Regression”

00/2 Spiros Bougheas, Panicos O. Demetrides and Edgar L.W. Morgenroth, "International Aspects of Public Infrastructure Investment"

00/3 Michael Bleaney, "Inflation as Taxation: Theory and Evidence" 


\section{Members of the Centre}

\section{Director}

Oliver Morrissey - aid policy, trade and agriculture

\section{Research Fellows (Internal)}

Adam Blake - CGE models of low-income countries

Mike Bleaney - growth, international macroeconomics

Indraneel Dasgupta - development theory

Norman Gemmell - growth and public sector issues

Ken Ingersent - agricultural trade

Tim Lloyd - agricultural commodity markets

Andrew McKay - poverty, peasant households, agriculture

Chris Milner - trade and development

Wyn Morgan - futures markets, commodity markets

Christophe Muller - poverty, household panel econometrics

Tony Rayner - agricultural policy and trade

\section{Research Fellows (External)}

V.N. Balasubramanyam (University of Lancaster) - foreign direct investment and multinationals

David Fielding (Leicester University) - investment, monetary and fiscal policy

Göte Hansson (Lund University) - trade, Ethiopian development

Robert Lensink (University of Groningen) - aid, investment, macroeconomics

Scott McDonald (Sheffield University) - CGE modelling, agriculture

Mark McGillivray (RMIT University) - aid allocation, human development

Jay Menon ( $A D B$, Manila) - trade and exchange rates

Doug Nelson (Tulane University) - political economy of trade

David Sapsford (University of Lancaster) - commodity prices

Finn Tarp (University of Copenhagen) - aid, CGE modelling

Howard White (IDS) - aid, poverty 